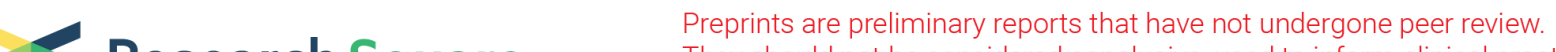 Research Square They should not be considered conclusive, used to inform clinical practice, or referenced by the media as validated information.
}

\section{Distribution Coefficients of Nitrogen Pollutants Between Water-Sediment And Their Environmental Risks In Lingang Hybrid Constructed Wetland Fed By Industrial Tailwater, Tianjin, China}

\section{Quanli Man}

Hebei University of Technology

\section{Hongrui Li}

Hebei University of Technology

Xiaodong Ma ( $\nabla$ maxd@hebut.edu.cn )

Hebei University of Technology

\section{Peng Gao}

Hebei University of Technology

\section{Gengbo Ren}

Hebei University of Technology

\section{Bin Zhou}

Tianjin Academy of Environmental Sciences

Honglei Liu

Tianjin Academy of Environmental Sciences

\section{Research Article}

Keywords: Hybrid constructed wetland, Nitrogen pollutants, Water-sediment, Distribution coefficients, Industrial tailwater

Posted Date: August 24th, 2021

DOI: https://doi.org/10.21203/rs.3.rs-727235/v1

License: (c) (1) This work is licensed under a Creative Commons Attribution 4.0 International License. Read Full License

Version of Record: A version of this preprint was published at Environmental Science and Pollution Research on December 1st, 2021. See the published version at https://doi.org/10.1007/s11356-02117741-7. 


\section{Abstract}

Exploring the fate of nitrogen pollutants in constructed wetlands (CWs) fed by industrial tailwater is significant to strengthen its pollution control and promoting the development of CWs in the field of micropolluted water treatment. In this study, the distribution coefficients and the environmental risks of nitrogen pollutants between water-sediment of the hybrid CW in Tianjin were systematically investigated. From a spatial perspective, the nitrogen pollutants could be removed in this hybrid $\mathrm{CW}$, and subsurface flow wetland played a key role in nitrogen pollutant removal. From a temporal perspective, the consistence of nitrogen pollutants was largely affected by the dissolved oxygen (DO) and temperature. The distribution coefficient of nitrogen pollutants between water-sediment was further clarified, suggesting that $\mathrm{NH}_{4}{ }^{+}-\mathrm{N}$ was more likely to be enriched in sediments due to microbial process. The overall level of pollution in hybrid CW was moderate according to the nutritional pollution index (NPI) analysis. The risks assessment indicated that timely dredging control measures should be considered to maintain the performance of hybrid CW.

\section{Introduction}

Constructed wetlands (CWs) have been regarded as a kind of environmentally friendly ecosystem that can perform advanced treatment of micro-polluted water (Wang et al. 2020; Wang et al. 2021). In order to realize the recycling of tail water of industrial sewage treatment plants, the number of CWs that use it as an influent source is increasing (Zhang et al. 2020; Zhu et al. 2021). Nitrogen pollutants are the main component of the tailwater of industrial sewage treatment plants. Due to the high emission of nitrogen pollutants from wastewater plants, it will inevitably pose a potential environmental risk to the CWs ecosystem. With this context, analyzing the occurrence characteristics of nitrogen pollutants between water-sediment in the CWs, it is important for pollution control.

The spatiotemporal distribution of nitrogen pollutants between water-sediment in CWs is usually related to microbial transformation, plant absorption and substrate adsorption (Zheng et al. 2016). For instance, nitrification of microorganisms is the main factor affecting the distribution variations of $\mathrm{NO}_{3}{ }^{-} \mathrm{N}$ and $\mathrm{NH}_{4}{ }^{+} \mathrm{N}$ in water, and the microorganisms in sediments mainly convert organic nitrogen into $\mathrm{NH}_{4}{ }^{+}-\mathrm{N}$ through ammonia oxidation (Zhang et al. 2014). Moreover, physical and chemical properties such as DO and temperature also affect the distribution of nitrogen pollutants between water-sediment. Previous studies have shown that the lower the temperature, the higher DO content. DO and temperature under appropriate conditions are conducive to the removal and transformation of $\mathrm{NH}_{4}{ }^{+}-\mathrm{N}$ and $\mathrm{NO}_{3}{ }^{-} \mathrm{N}(\mathrm{Li}$ et al. 2019; Ma et al. 2021). Therefore, understanding the spatiotemporal distribution of nitrogen pollutants between water-sediment has important guiding significance for optimizing the construction of the CWs.

In summary, studying the distribution of nitrogen pollutants between water-sediment was helpful to comprehending the whereabouts of nitrogen pollutants in the environmental media of CWs. Previous studies have indicated that there are obvious differences in the distribution of nitrogen pollutants 
between water-sediment due to the different effects of microorganisms. In addition, the physical and chemical properties such as DO and temperature in CWs will also affect the distribution of nitrogen pollutants by affecting the nitrification and ammonification of microorganisms. However, since the complexity of the actual structure of the CWs and the hydrogeological conditions, researchers still lack indepth understanding of the distribution of nitrogen between water-sediment of the CWs.

In this study, Lingang hybrid CW, Tianjin, which fed by the industrial tailwater, was selected as the object. In autumn and winter, sampling and testing the water and sediments of the hybrid CW: (1) to study the spatiotemporal variation characteristics of nitrogen contaminations between water-sediment of the hybrid CW, (2) to analyze the distribution law of nitrogen pollutants between water-sediment, (3) to assess the environmental risk of nitrogen pollutants in the hybrid CW by using the method of nutrient pollution index (NPI). The work for the understanding of the characteristics and distribution of nitrogen pollutants between water-sediment, strengthen hybrid CW ecosystem management and control is important.

\section{Materials And Methods}

\subsection{Study site and sample collection}

This site ( $\left.38^{\circ} 55^{\prime} 58^{\prime \prime} \mathrm{N}, 117^{\circ} 41^{\prime} 58^{\prime \prime} \mathrm{E}\right)$, is a hybrid constructed wetland ecosystem with the theme of industrial sewage treatment. In addition to the water inlet and outlet, the hybrid CW was roughly divided into four functional areas: Regulation Pond, Subsurface Flow Wetland (SSF CW), Surface Flow Wetland (SF CW) and Landscape Lake. The hybrid CW is about $6.3 \times 10^{5} \mathrm{~m}^{2}$, of which the water accounts for about $1.7 \times 10^{5} \mathrm{~m}^{2}$. In addition, the industrial tailwater of the Shengke wastewater treatment plant is the source of water in hybrid CW.

The study began in the autumn and winter seasons of 2019 (from August to December), and samples were collected on the first three days of each month. According to the hydrological characteristics of the hybrid CW, a total of 9 sampling points has been set up (Fig. 1). The collected water samples were put into polyethylene bottles, brought back and stored into the refrigerator at $4{ }^{\circ} \mathrm{C}$. The collected sediment samples were put into sealed bags and stored into the refrigerator at $-20^{\circ} \mathrm{C}$. All collected samples were tested within one week.

\subsection{Analysis methods}

In this study, the nitrogen pollutants included $\mathrm{TN}, \mathrm{NH}_{4}{ }^{+}-\mathrm{N}_{1} \mathrm{NO}_{3}{ }^{-}-\mathrm{N}$ and $\mathrm{NO}_{2}{ }^{-}-\mathrm{N}$. At the same time, $\mathrm{DO}$ and temperature will also affect the conversion of nitrogen pollutants. The methodology used to measure the above indicators are described in our previous work (Li et al. 2021). The data analyzed by Origin 2017, the relative deviation within $5 \%$.

\subsection{Quality assurance and quality control}


This research strictly complied with the environmental quality standards and adopted blank, repeated and standard reference analysis for nitrogen pollutants. Follow quality assurance and quality control procedures during sampling and analysis. Briefly, Milli-Q water was used to clean the outside of the bottle. Glass and polypropylene vessels were soaked in $10 \% \mathrm{HNO}_{3}$ of $48 \mathrm{~h}$ and rinsed with deionized water 3 times after apply. Each reagent and standard solution were guaranteed levels. Each sample was carried out in 3 replicates, and the mean as the final value.

\section{Results And Discussion}

\subsection{Spatiotemporal variations of nitrogen 3.1.1. Spatiotemporal variations of nitrogen in water}

In water, the spatial variation of nitrogen pollutants (Fig. 2). As shown in Fig. 2a, the consistence of $\mathrm{NO}_{3}{ }^{-}$$\mathrm{N}$ was between 0.31 and $1.46 \mathrm{mg} / \mathrm{L}$. On the whole, the consistence of $\mathrm{NO}_{3}{ }^{-}-\mathrm{N}$ fall and then raise along flow direction. In the regulation pond, the $\mathrm{NO}_{3}{ }^{-}-\mathrm{N}$ consistence droped by $0.13 \mathrm{mg} / \mathrm{L}$, which may be caused by the adsorption of sediment in the regulation pond (Tunçsiper 2020). Along the water flow direction, $\mathrm{NO}_{3}{ }^{-} \mathrm{N}$ flowed from the regulation pond to the SSF CW and SF CW, respectively. In the SSF CW, the consistence of $\mathrm{NO}_{3}{ }^{-}-\mathrm{N}$ changed greatly, and other study has reported that due to the presence of a large number of microbial (Zhao et al. 2021), $\mathrm{NH}_{4}{ }^{+}-\mathrm{N}$ could be easily converted into $\mathrm{NO}_{3}{ }^{-} \mathrm{N}$ by nitrification. Meanwhile, the $\mathrm{NO}_{3}{ }^{-} \mathrm{N}$ consistence decreased to $0.36 \mathrm{mg} / \mathrm{L}$ in the SFW, which may be related to the absorption of plants such as reeds. From the landscape lakes to the water outlet, the $\mathrm{NO}_{3}{ }^{-}{ }^{-} \mathrm{N}$ consistence increased slightly from 0.31 to $0.42 \mathrm{mg} / \mathrm{L}$. This is attributed to the microorganism produced part of $\mathrm{NO}_{3}{ }^{-}$$\mathrm{N}$ through nitrification (Li et al. 2019).

Similarly, the spatial changes of $\mathrm{NH}_{4}{ }^{+}-\mathrm{N}$ were shown in Fig. 2b. Overall, the consistence of $\mathrm{NH}_{4}{ }^{+}-\mathrm{N}$ between 0.15 and $0.6 \mathrm{mg} / \mathrm{L}$ and showed first decreased and then increased along flow direction. Compared with other functional areas, the content of $\mathrm{NH}_{4}{ }^{+}-\mathrm{N}$ in SSF CW was relatively low $(0.15 \mathrm{mg} / \mathrm{L})$. Our obtained results were consistent with previous research, who assumed that nitrification by microorganisms and adsorption by substrates will occur in SSF CW (Langergraber et al. 2009; Zhao et al. 2021). The spatial variation of $\mathrm{NO}_{2}{ }^{-} \mathrm{N}$ in hybrid $\mathrm{CW}$ was shown in Fig. 2c. The maximum consistence of $\mathrm{NO}_{2}{ }^{-}-\mathrm{N}$ was not more than $0.022 \mathrm{mg} / \mathrm{L}$ in hybrid $\mathrm{CW}$, which could be ignored. This could be due to $\mathrm{NO}_{2}{ }^{-}-\mathrm{N}$ was the intermediate product of nitrification, and easy to be converted (Li et al. 2018). At the water inlet, the $\mathrm{NO}_{2}{ }^{-}-\mathrm{N}$ consistence was relatively high, which may be caused by the discharge from the sewage treatment plant.

As shown in Fig. 2d, the consistence of TN ranged from 1.72 to $3.64 \mathrm{mg} / \mathrm{L}$, which indicated a downward trend overall and slightly increased at the outlet. It could be inferred from the Fig. 2 that $\mathrm{NO}_{3}{ }^{-} \mathrm{N}$ has a 
large proportion in $\mathrm{TN}$ and was the most important form of nitrogen.

Correspondingly, Fig. 3 showed that the temporal variation of nitrogen from August to December in hybrid $\mathrm{CW}$. Overall, the consistence of $\mathrm{NO}_{3}{ }^{-}-\mathrm{N}$ first decrease and then increased with time (Fig. 3a). As the temperature decreases slowly, plants were still undergoing absorption despite the hindrance of nitrification, causing the content of $\mathrm{NO}_{3}{ }^{-} \mathrm{N}$ dropped from 1.02 to $0.28 \mathrm{mg} / \mathrm{L}$ before October. Next, its gradually increased to $0.74 \mathrm{mg} / \mathrm{L}$ in December, which could be attributed to the large number of plant deaths and could not absorbed by temperature decrease. Meanwhile, when the temperature was lower than $15^{\circ} \mathrm{C}$ in December, nitrification and denitrification could not be carried out effectively, leading to the slightly accumulated of $\mathrm{NO}_{3}{ }^{-}-\mathrm{N}$.

Analogously, Fig. 3b showed the temporal variation of $\mathrm{NH}_{4}{ }^{+}-\mathrm{N}$. Observed that the $\mathrm{NH}_{4}{ }^{+}-\mathrm{N}$ consistence shows an overall upward trend with time (from 0.10 to $0.63 \mathrm{mg} / \mathrm{L}$ ), which could be due to the slowing down of nitrification and the large number of plant death as the temperature gradually decreases (Ding et al. 2018). As shown in Fig. 3c, the consistence of $\mathrm{NO}_{2}{ }^{-}-\mathrm{N}$ changes with time. Interestingly, the fluctuation range of $\mathrm{NO}_{2}{ }^{-}-\mathrm{N}$ content was smaller in time. Hence, it could be included that the temporal and spatial changes of $\mathrm{NO}_{2}{ }^{-}-\mathrm{N}$ were consistent.

The temporal variation of TN consistence was shown in Fig. 3d. From August to September, it showed an upward trend from $2.20 \mathrm{mg} / \mathrm{L}$ to $2.66 \mathrm{mg} / \mathrm{L}$. The variation trend of TN consistence from September to December was similar to $\mathrm{NO}_{3}{ }^{-}-\mathrm{N}$. The TN consistence showed a downward trend from 2.66 to $1.70 \mathrm{mg} / \mathrm{L}$, and then gradually increased to $2.05 \mathrm{mg} / \mathrm{L}$ in December. It can be concluded from Fig. 3 that $\mathrm{NO}_{3}{ }^{-} \mathrm{N}$ accounts for the highest proportion of TN in the temporal variation, which was also reported in previous studies (Li et al. 2015).

\subsubsection{Spatiotemporal variation of nitrogen in sediments}

The spatial variation of nitrogen pollutant consistence in sediments of hybrid CW was shown in Fig. 4. As shown in Fig. 4a, the content of $\mathrm{NO}_{3}{ }^{-}-\mathrm{N}$ in sediments flowed from the water inlet to the SSF CW and the SF CW, and all of them showed a slight downward from 2.37 to 1.19 and $1.37 \mathrm{mg} / \mathrm{kg}$, respectively. This is attribute to the substrate adsorption of in the SF CW and the plants absorption in the SSF CW (Saeed and Sun 2012). In the landscape lake, the $\mathrm{NO}_{3}{ }^{-} \mathrm{N}$ consistence decreased to $0.72 \mathrm{mg} / \mathrm{kg}$, which may be due to the low DO in the landscape lake sediments. At the same time, in the hypoxic environment, the nitrification of microorganisms slows down, and it is conducive to the progress of denitrification (Hong et al. 2019). After that, it showed a slight upward trend at the water outlet (up to $1.32 \mathrm{mg} / \mathrm{kg}$ ), which may be due to the flow rate of the water outlet was slow and the sediment fully adsorbed $\mathrm{NO}_{3}{ }^{-} \mathrm{N}$ in water.

The spatial variation of $\mathrm{NH}_{4}{ }^{+}-\mathrm{N}$ in sediments was shown in Fig. 4b. At the water inlet, the $\mathrm{NH}_{4}{ }^{+}-\mathrm{N}$ consistence a was $103.28 \mathrm{mg} / \mathrm{kg}$. The $\mathrm{NH}_{4}{ }^{+}-\mathrm{N}$ consistence from the regulation pond to the water outlet was 51.52 to $68.48 \mathrm{mg} / \mathrm{kg}$. Except for the water inlet, the $\mathrm{NH}_{4}{ }^{+}-\mathrm{N}$ consistence in other regions has little 
difference. However, it was obviously higher in sediments than that in water, which was mainly attributed to two aspects: on the one hand, the adsorption of the matrix leads to the migration of $\mathrm{NH}_{4}{ }^{+}-\mathrm{N}$ in water to sediments (Wu et al. 2018); On the other hand, the $\mathrm{NH}_{4}{ }^{+}-\mathrm{N}$ in sediments mainly came from the mineralization process of total organic nitrogen (TON) (Zhu et al. 2019). And the low DO in the sediments slows down nitrification, which lead to an upward trend of $\mathrm{NH}_{4}{ }^{+}-\mathrm{N}$ accumulation in the sediments.

According to Fig. 4c, the consistence of $\mathrm{NO}_{2}{ }^{-}-\mathrm{N}$ was extremely low due to poor stability (range from 0.009 to $0.032 \mathrm{mg} / \mathrm{kg}$ ).

The spatial variation of TN in sediments was shown in Fig. $4 \mathrm{~d}$. The variation trend of TN consistence in sediments was similar to $\mathrm{NH}_{4}{ }^{+} \mathrm{N}$. The consistence of $\mathrm{TN}$ ranged from 252.40 to $414.84 \mathrm{mg} / \mathrm{kg}$. TN at the water inlet was high $(414.84 \mathrm{mg} / \mathrm{kg})$, then decreased to $358.76 \mathrm{mg} / \mathrm{kg}$ in the regulation pond, and with little change in the SSF CW and SF CW (337.88 and $347.00 \mathrm{mg} / \mathrm{kg}$ respectively). It decreased to 252.40 $\mathrm{mg} / \mathrm{kg}$ in the landscape lake, and final recovered slightly to $253.60 \mathrm{mg} / \mathrm{kg}$.

The temporal variation of $\mathrm{NO}_{3}{ }^{-}-\mathrm{N}$ in sediments was shown in Fig. 5a. The $\mathrm{NO}_{3}{ }^{-}-\mathrm{N}$ consistence changed in a small range from August to December (ranging from 0.82 to $1.37 \mathrm{mg} / \mathrm{kg}$ ), which is related to the consistence of DO. Low consistence of DO in sediments, is key limiting nitrification for removal of $\mathrm{NO}_{3}{ }^{-}$$\mathrm{N}$.

The $\mathrm{NH}_{4}{ }^{+} \mathrm{N}$ consistence fluctuated greatly from August to December. In August, the consistence of $\mathrm{NH}_{4}{ }^{+}-$ $\mathrm{N}$ was only $24.00 \mathrm{mg} / \mathrm{kg}$. This is related to the migration of pollutants in water. By comparison, it is found that the consistence of this pollutant in the water is also low. After that, the $\mathrm{NH}_{4}{ }^{+}-\mathrm{N}$ consistence showed an upward trend in September and October (95.12 and $91.76 \mathrm{mg} / \mathrm{kg}$, respectively). This may be due to the increase of $\mathrm{NH}_{4}{ }^{+}-\mathrm{N}$ content in water, resulting in a corresponding increase in sediments, and the mineralization of organic nitrogen also produced part of $\mathrm{NH}_{4}{ }^{+} \mathrm{N}$ (Zhu et al. 2019). However, the $\mathrm{NH}_{4}{ }^{+}-\mathrm{N}$ consistence in November and December is 56.80 and $60.16 \mathrm{mg} / \mathrm{kg}$, respectively. Since the effect of temperature on microorganism activity and mineralization, $\mathrm{NH}_{4}{ }^{+}-\mathrm{N}$ consistence decreased slightly (Ding et al. 2018). As shown in Fig. 5c, the $\mathrm{NO}_{2}{ }^{-}-\mathrm{N}$ consistence remained at a low level (much less than 0.032 $\mathrm{mg} / \mathrm{kg}$ ) and didn't change significantly over time.

The variation trend of $\mathrm{TN}$ in sediments from August to December was similar to that of $\mathrm{NH}_{4}{ }^{+}-\mathrm{N}$. It increased from 246.36 to $414.84 \mathrm{mg} / \mathrm{kg}$ (Fig. 5d), then decreased to $282.88 \mathrm{mg} / \mathrm{kg}$ in November, and then increased slightly in December (345.92 mg/kg). Therefore, it could be known that $\mathrm{NH}_{4}{ }^{+} \mathrm{N}$ accounts for the highest proportion of TN, which had been similarly reported in previous studies (Zhu et al. 2019).

\subsection{Distribution coefficient of nitrogen pollutants between water-sediment}


The distribution of nitrogen pollutants between water-sediment was one of the important factors to analyze the rule of migration and transformation. The distribution coefficient $\left(K_{d}\right)$ can be used to evaluate the distribution of pollutants between water-sediment. $K_{d}$ is calculated according to the consistence ratio between water-sediment (Tang et al. 2019), and its calculation formula is as follows:

$K_{d}=\frac{C_{s}}{C_{w}}$

In which $C_{s}$ and $C_{w}$ represents the consistence of nitrogen pollutants in sediment and in water, respectively.

The $K_{d}$ values of $\mathrm{N}$ in hybrid $\mathrm{CW}$ with the spatiotemporal variation were shown in Table 1 and Table 2. As can be seen from Table 1, the average $K_{d}$ values of $\mathrm{NO}_{3}{ }^{-}-\mathrm{N}, \mathrm{NH}_{4}{ }^{+}-\mathrm{N}, \mathrm{NO}_{2}{ }^{-}-\mathrm{N}$ and TN in different areas of hybrid CW were $2.19 \mathrm{~L} / \mathrm{kg}, 204.79 \mathrm{~L} / \mathrm{kg}, 3.75 \mathrm{~L} / \mathrm{kg}$ and $136.95 \mathrm{~L} / \mathrm{kg}$, respectively. And it from Table 2 were $2.59 \mathrm{~L} / \mathrm{kg}, 198.33 \mathrm{~L} / \mathrm{kg}, 2.34 \mathrm{~L} / \mathrm{kg}$ and $157.29 \mathrm{~L} / \mathrm{kg}$, respectively. It could be seen that the mean $K_{d}$ of $\mathrm{NH}_{4}{ }^{+}-\mathrm{N}$ and TN were significantly higher than $\mathrm{NO}_{3}{ }^{-}-\mathrm{N}$ and $\mathrm{NO}_{2}{ }^{-}-\mathrm{N}$. In conjunction with the Fig. 6\&7, which indicated that sediments have a strong adsorption effect on $\mathrm{NH}_{4}{ }^{+} \mathrm{N}$ and TN. Therefore, the influence of $\mathrm{NH}_{4}{ }^{+}-\mathrm{N}$ and $\mathrm{TN}$ in water was less than that in sediments, and they were more easily enriched in sediments than in water, which was parallels previous reports (Zhu et al. 2019). However, the average $K_{d}$ values of $\mathrm{NO}_{3}{ }^{-}-\mathrm{N}$ and $\mathrm{NO}_{2}{ }^{-}-\mathrm{N}$ were small, which indicated both of that the adsorption effects between watersediments were not different.

Table 1

Distribution coefficient of different regions of hybrid CW $(\mathrm{L} / \mathrm{kg})$

\begin{tabular}{|c|c|c|c|c|c|c|c|}
\hline & $\begin{array}{l}\text { Water } \\
\text { inlet }\end{array}$ & $\begin{array}{l}\text { Regulation } \\
\text { pond }\end{array}$ & $\begin{array}{l}\text { SSF } \\
\text { CW }\end{array}$ & SF CW & $\begin{array}{l}\text { Landscape } \\
\text { lake }\end{array}$ & $\begin{array}{l}\text { Water } \\
\text { outlet }\end{array}$ & Mean \\
\hline $\begin{array}{l}\mathrm{NO}_{3}{ }^{-}- \\
\mathrm{N}\end{array}$ & 1.63 & 1.23 & 0.98 & 3.81 & 2.34 & 3.12 & 2.19 \\
\hline $\begin{array}{l}\mathrm{NH}_{4}{ }^{+}- \\
\mathrm{N}\end{array}$ & 173.29 & 172.93 & 354.29 & 195.42 & 175.27 & 157.55 & 204.79 \\
\hline $\begin{array}{l}\mathrm{NO}_{2}{ }^{-}- \\
\mathrm{N}\end{array}$ & 1.65 & 1.45 & 11.5 & 1.33 & 1.29 & 5.25 & 3.75 \\
\hline TN & 113.87 & 112.25 & 134.61 & 177.86 & 147.00 & 136.12 & 136.95 \\
\hline
\end{tabular}


Table 2

Distribution coefficient of hybrid CW in different months $(\mathrm{L} / \mathrm{kg})$

\begin{tabular}{|lllllll|}
\hline & $\mathbf{8}$ & $\mathbf{9}$ & 10 & 11 & 12 & Mean \\
\hline $\mathrm{NO}_{3}{ }^{-} \mathrm{N}$ & 0.80 & 3.54 & 2.53 & 4.23 & 1.84 & 2.59 \\
\hline $\mathrm{NH}_{4}{ }^{+} \mathrm{N}$ & 244.90 & 286.51 & 231.72 & 133.02 & 95.49 & 198.33 \\
\hline $\mathrm{NO}_{2}{ }^{-} \mathrm{N}$ & 4.00 & 3.25 & 0.94 & 2.00 & 1.50 & 2.34 \\
\hline $\mathrm{TN}$ & 111.93 & 123.75 & 216.06 & 166.11 & 168.58 & 157.29 \\
\hline
\end{tabular}

Pearson correlation analysis of nitrogen pollutants in different areas of CWs is made. The distribution of $\mathrm{NH}_{4}{ }^{+} \mathrm{N}$ and TN has a good correlation between water-sediment (the correlation coefficients are 0.91 and 0.87 , respectively), indicating that when its consistence in water was higher and will also increase significantly in sediment ( $\mathrm{Li}$ et al. 2020), which was consistent with the above spatial and temporal distribution results.

\subsection{Environmental risk assessment}

Nutritional pollution index (NPI) can effectively describe the pollution of nitrogen pollutants to water quality and environment (Isiuku and Enyoh 2020). In addition to $\mathrm{NO}_{2}{ }^{-}-\mathrm{N}$, the above three forms of nitrogen were important factors causing water eutrophication. Therefore, the pollution analysis of $\mathrm{NO}_{3}{ }^{-} \mathrm{N}$, $\mathrm{NH}_{4}{ }^{+}-\mathrm{N}$ and $\mathrm{TN}$ was carried out $\left(\mathrm{NO}_{2}{ }^{-}-\mathrm{N}\right.$ is not considered because of its small content in water). The NPI calculation formula was as follows:

$N P I=\frac{C_{1}}{M A C_{1}}+\frac{C_{2}}{M A C_{2}}+\frac{C_{3}}{M A C_{3}}$

$C_{1}, C_{2}$ and $C_{3}$ represent the average consistence of $\mathrm{NO}_{3}{ }^{-}-\mathrm{N}_{1} \mathrm{NH}_{4}{ }^{+}-\mathrm{N}$ and $\mathrm{TN}$ in water, respectively. And $M A C_{1}, M A C_{2}$ and $M A C_{3}$ in turn correspond to the above maximum standard consistence, which are 20 , 1.5 and $1.5 \mathrm{mg} / \mathrm{L}$ respectively. Classification criteria of $\mathrm{NPI}$ are: $\mathrm{NPI}<1$ (no pollution), $1 \leq \mathrm{NPI} \leq 3$ (moderate pollution), $3<\mathrm{NPI} \leq 6$ (high pollution) and NPI $>6$ (severe pollution).

The distribution results of nutrition pollution index (NPI) were shown in Table 3 and Fig. 8. It can be found that the NPI at the water inlet was 3.09, which was a high pollution level, which may be due to the consistence of wastewater containing nitrogen pollutants discharged from the water inlet was higher than the standard of the water. Except the water inlet, the pollution levels of other areas are all moderate pollution. TN consistence in the whole was higher than the standard level. Combined with the spatiotemporal changes of nitrogen pollutant between water-sediment, it can be inferred that $\mathrm{NO}_{3}{ }^{-} \mathrm{N}^{-}$in water is the main component that causes moderate pollution in hybrid CW. In the sediment, it contains a 
large amount of $\mathrm{NH}_{4}{ }^{+} \mathrm{N}$ and $\mathrm{TN}$, and there is a risk of secondary release. Therefore, it is recommended to take preventive measures for timely dredging of the hybrid CW.

Table 3

Nutritional pollution index

\begin{tabular}{|lllllll|}
\hline & Water inlet & Regulation pond & SSF CW & SF CW & Landscape lake & water outlet \\
\hline NPI & 3.09 & 2.46 & 2.14 & 1.73 & 1.47 & 1.46 \\
\hline
\end{tabular}

\section{Conclusion}

In this study, the spatiotemporal variation characteristics of nitrogen between water-sediment of hybrid CW were analyzed, and the environmental risk was studied. The results showed that the main nitrogen form was $\mathrm{NO}_{3}{ }^{-}-\mathrm{N}(0.31-1.46 \mathrm{mg} / \mathrm{L})$ in water, while $\mathrm{NH}_{4}{ }^{+}-\mathrm{N}(51.52-103.28 \mathrm{mg} / \mathrm{L})$ was the main nitrogen form in sediments. The distribution coefficient showed that has a strong adsorption effect on $\mathrm{NH}_{4}{ }^{+}-\mathrm{N}^{-}$and $\mathrm{TN}$, and both of which were more easily enriched in the sediment. By comparing the experimental results, the consistence of nitrogen pollutants had a positive correlation between water and sediments. In addition, the nutrition pollution index (NPI) showed that the wetland as a whole was at a moderate pollution level, and $\mathrm{NO}_{3}{ }^{-}-\mathrm{N}$ was the important factor affecting the water pollution of hybrid $\mathrm{CW}$.

\section{Declarations}

\section{Ethics approval and consent to participate}

This manuscript does not contain any studies with human participants or animals performed by any of the authors.

\section{Consent for publication}

All authors give consent to publish the research in Environmental Science and Pollution Research.

\section{Availability of data and material}

All relevant data generated or analyzed during this study were included in this published article.

\section{Competing interests}

The authors declare that they have no competing interests.

\section{Funding}

The National Natural Science Foundation of China (No. 21876042), the Ministry of Science and Technology of the People's Republic of China (No. 2020YFC1808603), Natural Science Foundation of 
Hebei Province (No. B2019202200, B2020202061 and B2020202057) and the S\&T Program of Hebei (No. 21374204D).

\section{Author's contributions}

Xiaodong Ma, Gengbo Ren and Hongrui Li conceived and designed the study. Hongrui Li and Peng Gao performed experiments. Quanli Man and Hongrui Li wrote the manuscript. Xiaodong Ma, Gengbo Ren, Bin Zhou and Honglei Liu revised the manuscript. All authors read and approved the final manuscript.

\section{Acknowledgment}

The authors gratefully acknowledge financial support for this work from the National Natural Science Foundation of China (No. 21876042), the Ministry of Science and Technology of the People's Republic of China (No. 2020YFC1808603), Natural Science Foundation of Hebei Province (No. B2019202200, B2020202061 and B2020202057) and the S\&T Program of Hebei (No. 21374204D).

\section{References}

1. Ding X, Xue Y, Zhao Y, Xiao W, Liu Y, Liu J (2018) Effects of different covering systems and carbon nitrogen ratios on nitrogen removal in surface flow constructed wetlands. J Clean Prod 172:541-551

2. Hong Y, Wu J, Guan F, Yue W, Long A (2019) Nitrogen removal in the sediments of the Pearl River Estuary, China: Evidence from the distribution and forms of nitrogen in the sediment cores. Mar Pollut Bull 138:115-124

3. Isiuku BO, Enyoh CE (2020) Pollution and health risks assessment of nitrate and phosphate consistences in water bodies in South Eastern, Nigeria. Environ Adv 2:100018

4. Langergraber G, Leroch K, Pressl A, Sleytr K, Rohrhofer R, Haberl R (2009) High-rate nitrogen removal in a two-stage subsurface vertical flow constructed wetland. Desalination 246:55-68

5. Li D, Huang D, Guo C, Guo X (2015) Multivariate statistical analysis of temporal-spatial variations in water quality of a constructed wetland purification system in a typical park in Beijing, China. Environ Monit Assess 187:1-14

6. Li X, Li Y, Li Y, Wu J (2019) Enhanced nitrogen removal and quantitative analysis of removal mechanism in multistage surface flow constructed wetlands for the large-scale treatment of swine wastewater. J Environ Manage 246:575-582

7. Li HR, Ma XD, Zhou B, Ren GB, Yuan DK, Liu HL, Wei ZZ, Gu XJ, Zhao B, Hu YH, Wang HG (2021) An integrated migration and transformation model to evaluate the occurrence characteristics and environmental risks of Nitrogen and phosphorus in constructed wetland. Chemosphere 277

8. Li X, Li Y, Lv D, Li Y, Wu J (2020) Nitrogen and phosphorus removal performance and bacterial communities in a multi-stage surface flow constructed wetland treating rural domestic sewage. Sci Total Environ 709:136235 
9. Li YH, Li HB, Xu XY, Wang SQ, Pan J (2018) Does carbon-nitrogen ratio affect nitrous oxide emission and spatial distribution in subsurface wastewater infiltration system? Bioresource Technol 250:846852

10. Ma XJ, Xu HD, Wang LP (2021) Characteristics of bacterial population of water from Tianjin Lingang Coastal Wetland Park. J Environ Eng Tech 11:437-447

11. Saeed T, Sun G (2012) A review on nitrogen and organics removal mechanisms in subsurface flow constructed wetlands: dependency on environmental parameters, operating conditions and supporting media. J Environ Manage 112:429-448

12. Tang J, Wang S, Fan J, Long S, Wang L, Tang C, Tam NF, Yang Y (2019) Predicting distribution coefficients for antibiotics in a river water-sediment using quantitative models based on their spatiotemporal variations. Sci Total Environ 655:1301-1310

13. Tunçsiper $B$ (2020) Nitrogen removal in an aerobic gravel filtration-sedimentation pond-constructed wetland-overland flow system treating polluted stream waters: Effects of operation parameters. Sci Total Environ 746:140577

14. Wang J, Xia L, Chen J, Wang X, Wu H, Li D, Wells GF, Yang J, Hou J, He X (2020) Synergistic simultaneous nitrification-endogenous denitrification and EBPR for advanced nitrogen and phosphorus removal in constructed wetlands. Chem Eng J, 127605

15. Wang HP, Chang H, Zhang CX, Feng CL, Wu FC (2021) Occurrence of chlorinated paraffins in a wetland ecosystem: removal and distribution in plants and sediments. Environ Sci Technol 55:9941033

16. Wu HM, Ma WM, Kong Q, Liu H (2018) Spatial-temporal dynamics of organics and nitrogen removal in surface flow constructed wetlands for secondary effluent treatment under cold temperature. Chem Eng J 350:445-452

17. Yang Y, Liu J, Zhang N, Xie H, Zhang J, Hu Z, Wang Q (2019) Influence of application of manganese ore in constructed wetlands on the mechanisms and improvement of nitrogen and phosphorus removal. Ecotox Environ Safe 170:446-452

18. Zhang GZ, Ma K, Zhang ZX, Shang XB, Wu FP (2020) Waste brick as constructed wetland fillers to treat the tail water of sewage treatment plant. Bull Environ Contamination Toxic 104:273-281

19. Zhang L, Wang S, Wu Z (2014) Coupling effect of pH and dissolved oxygen in water column on nitrogen release at water-sediment interface of Erhai Lake, China. Estuar Coast Shelf S 149:178-186

20. Zhao L, Fu GP, Wu JF, Pang WC, Hu ZL (2021) Bioaugmented constructed wetlands for efficient saline wastewater treatment with multiple denitrification pathways. Bioresource Technol 325

21. Zheng Y, Wang X, Dzakpasu M, Zhao Y, Ngo HH, Guo W, Ge Y, Xiong J (2016) Effects of interspecific competition on the growth of macrophytes and nutrient removal in constructed wetlands: A comparative assessment of free water surface and horizontal subsurface flow systems. Bioresource Technol 207:134-141

22. Zhu TD, Gao JQ, Huang ZZ, Shang N, Gao JL, Zhang JL, Cai M (2021) Comparison of two large-scale vertical-flow constructed wetlands treating wastewater treatment plant tail-water: contaminants 
removal and associated microbial community. J Environ Mana 278:1

23. Zhu Y, Jin X, Tang W, Meng X, Shan B (2019) Comprehensive analysis of nitrogen distributions and ammonia nitrogen release fluxes in the sediments of Baiyangdian Lake, China. J Environ Sci 76:319-328

\section{Figures}

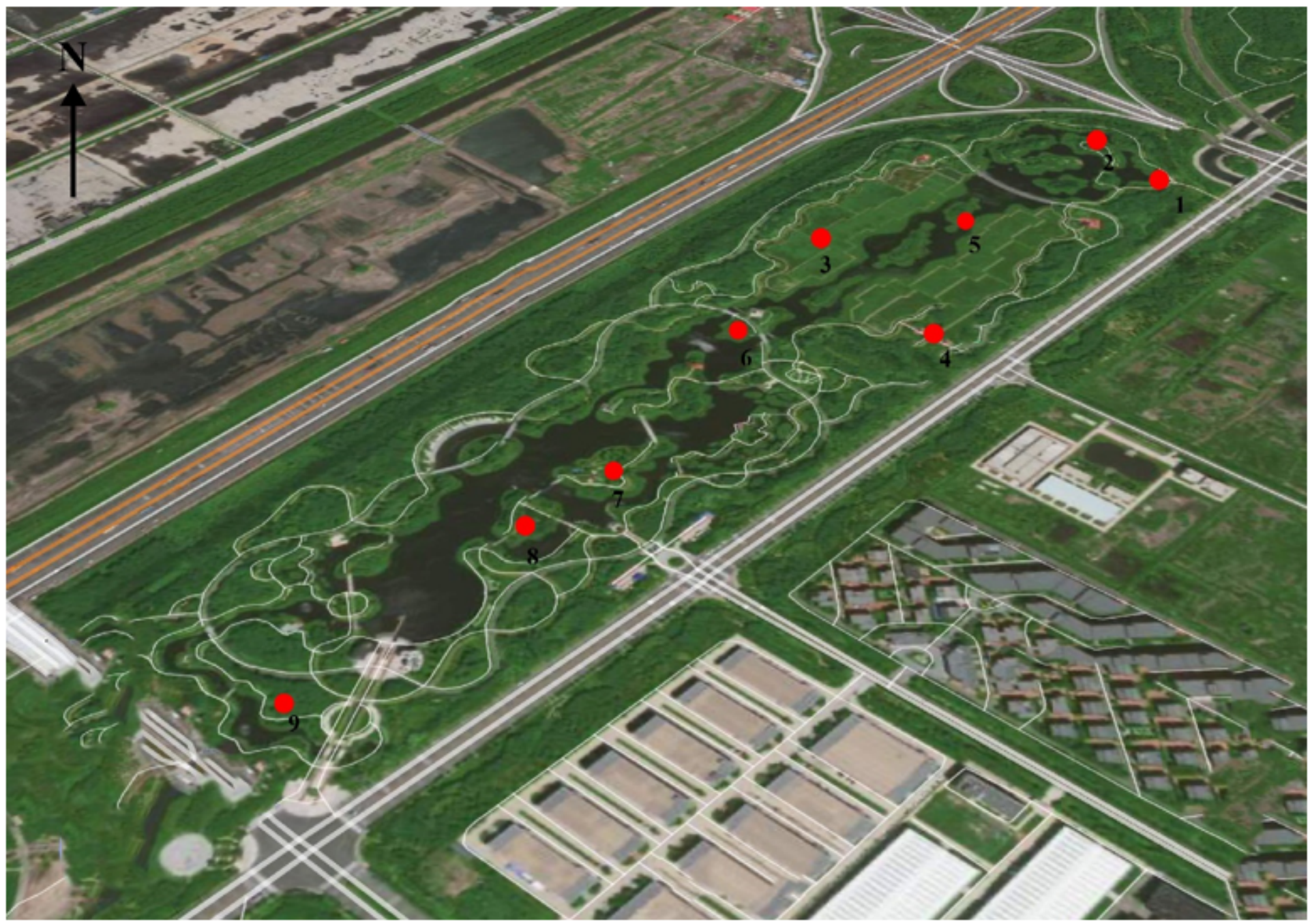

\section{Figure 1}

CW sampling point layout 1: from water inlet; 2: from regulation pond; 3-4: from subsurface flow wetland (SSF CW); 5: from surface flow wetland (SF CW); 6-8: from landscape lake; 9: water outlet 

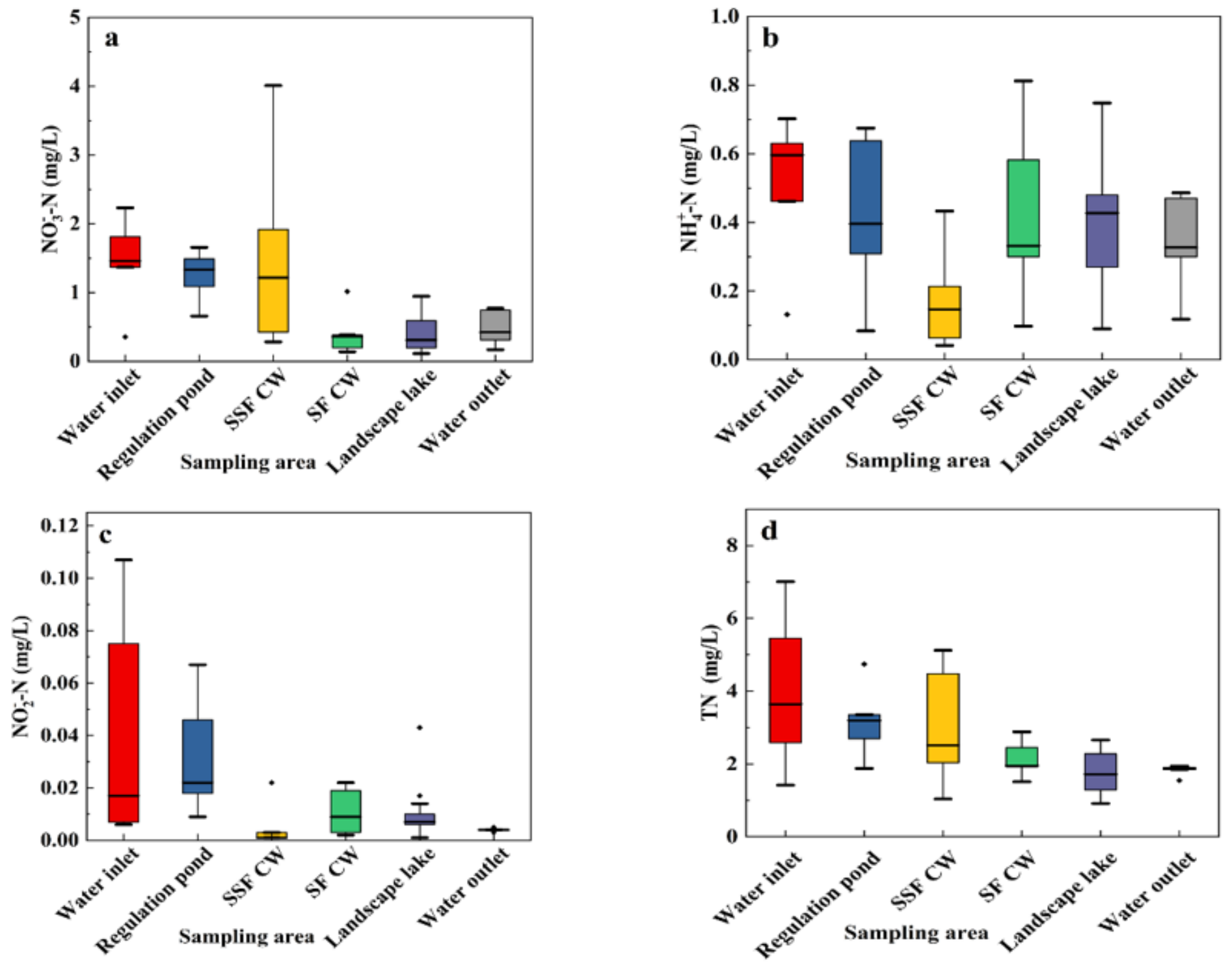

Figure 2

Spatial variation of (a) NO3--N, (b) NH4+-N, (c) NO3-N, (d) TN in water 

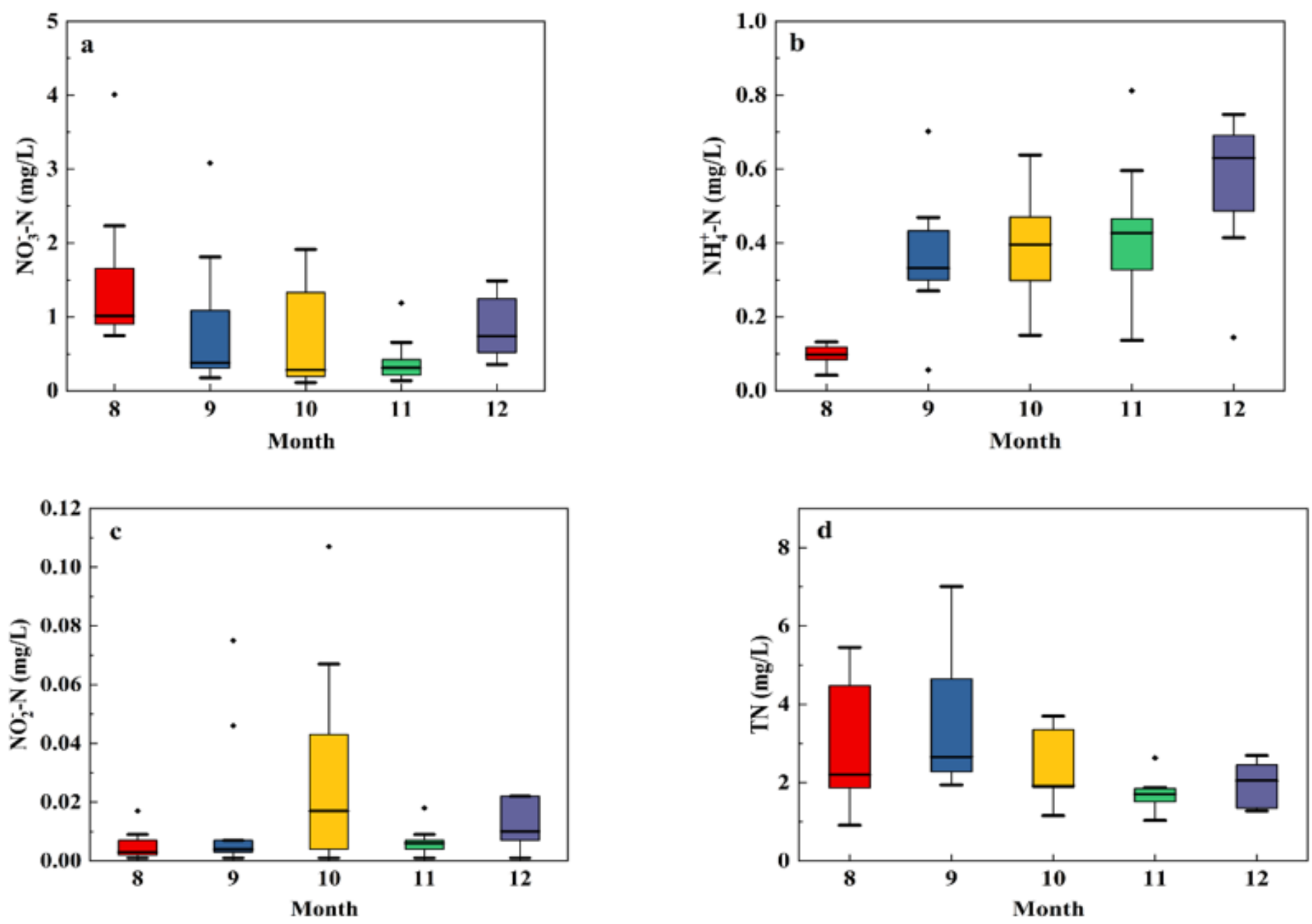

Figure 3

Temporal variation of (a) NO3-N, (b) NH4+-N, (c) NO2--N and (d) TN in water 

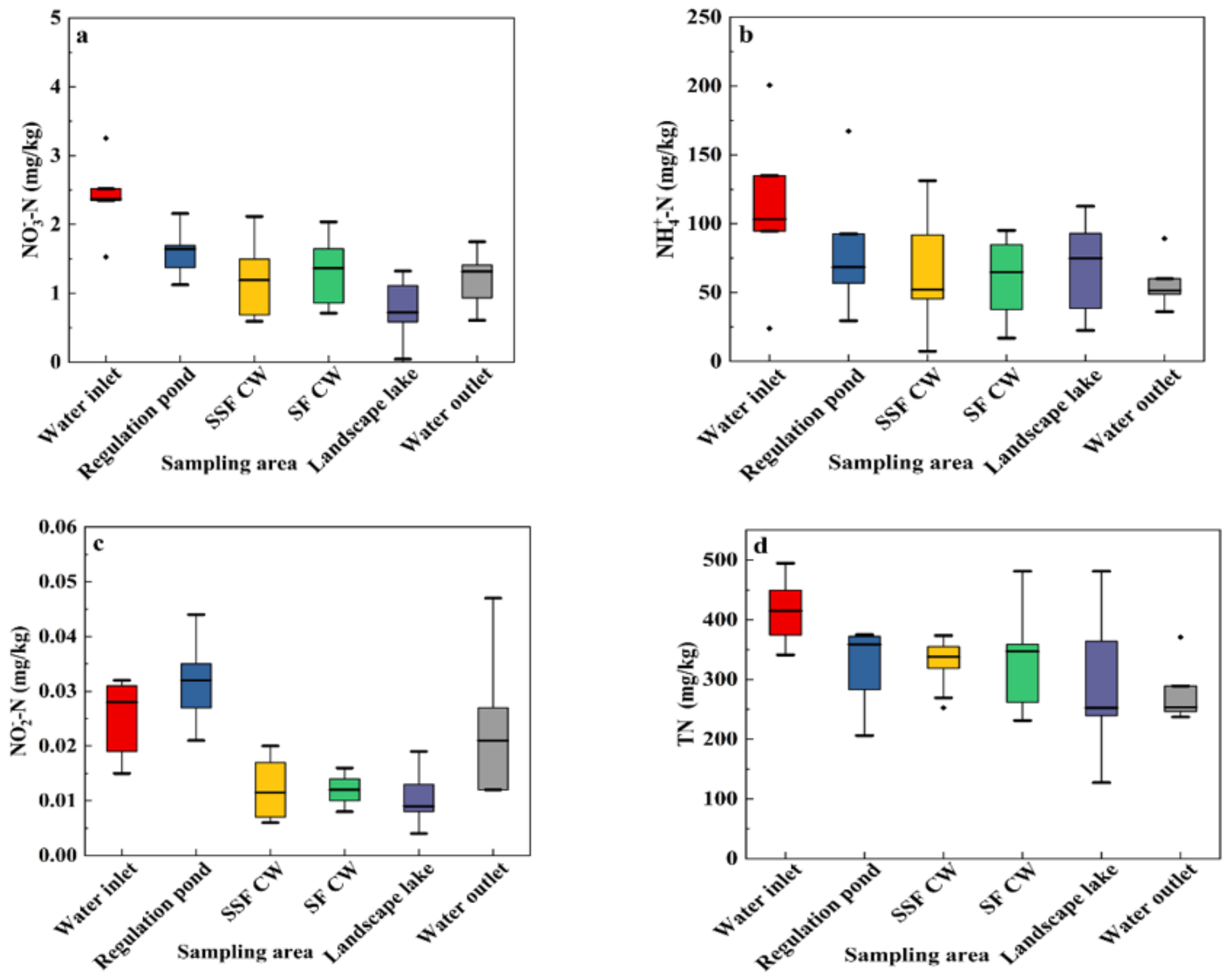

Figure 4

Spatial variation of (a) NO3--N, (b) NH4+-N, (c) NO2-N and (d) TN in sediments 

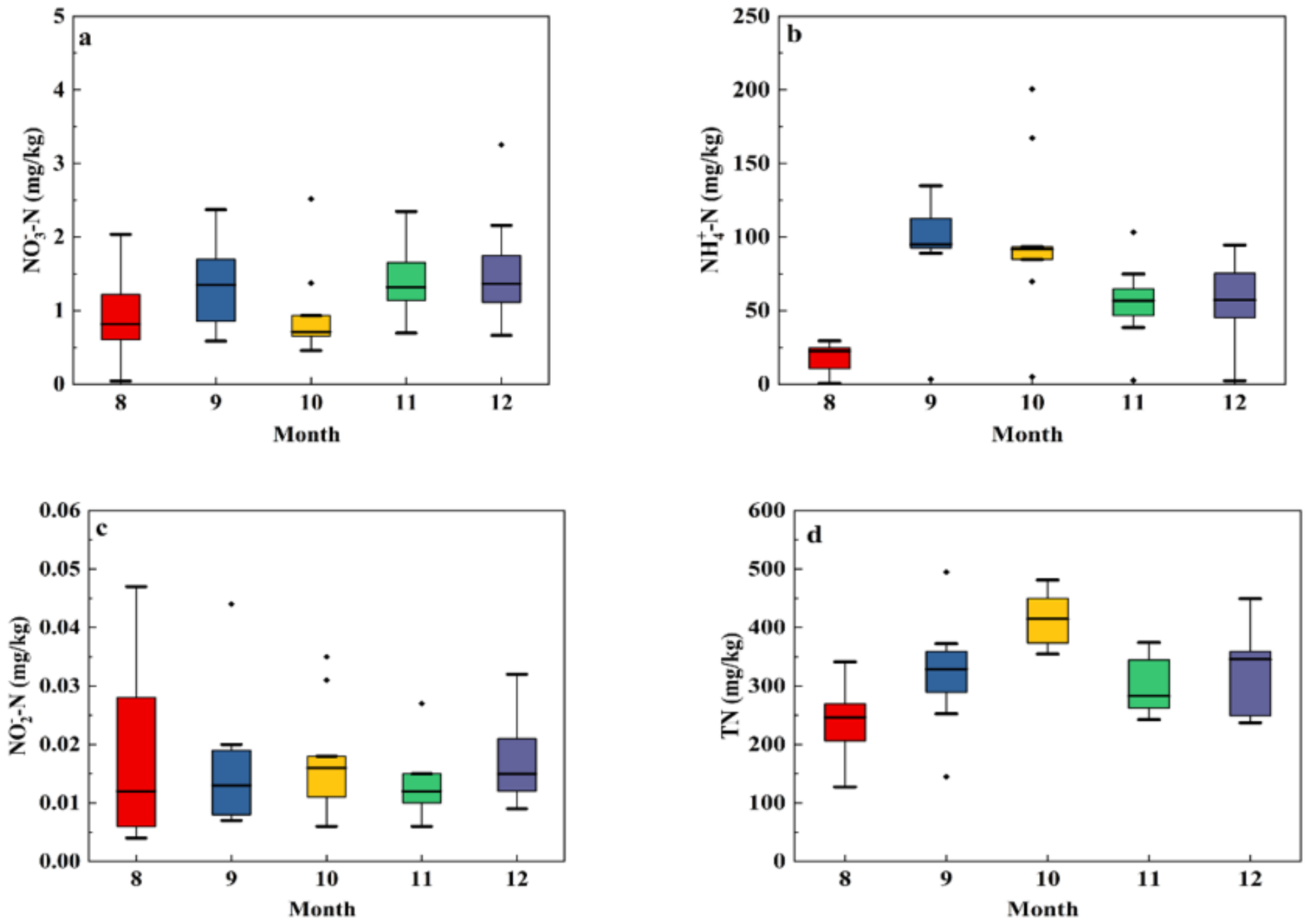

Figure 5

Temporal distribution of (a) NO3-N, (b) NH4+-N, (c) NO2--N and (d) TN in sediments 


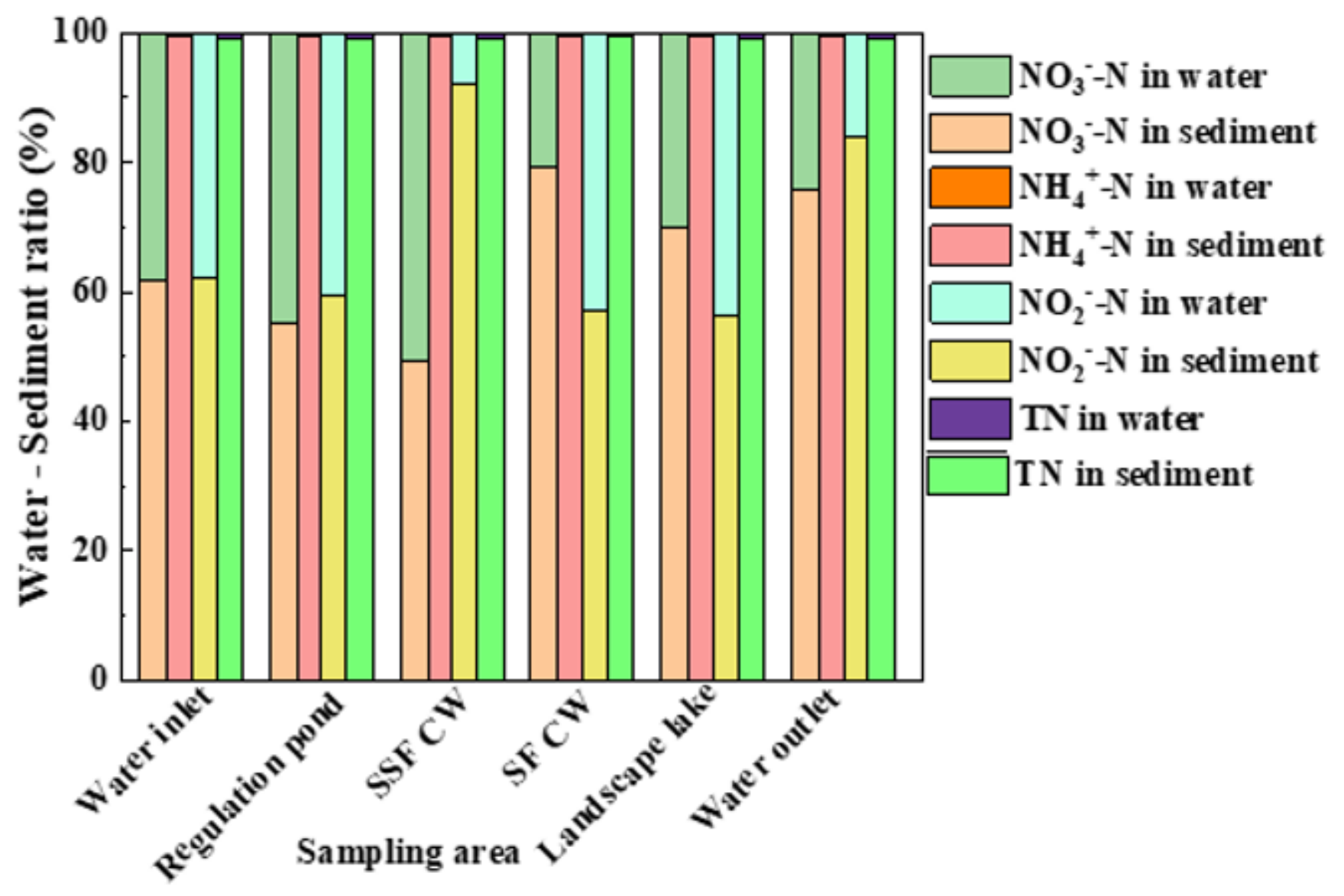

Figure 6

Spatial distribution of nitrogen pollutants in hybrid CW 


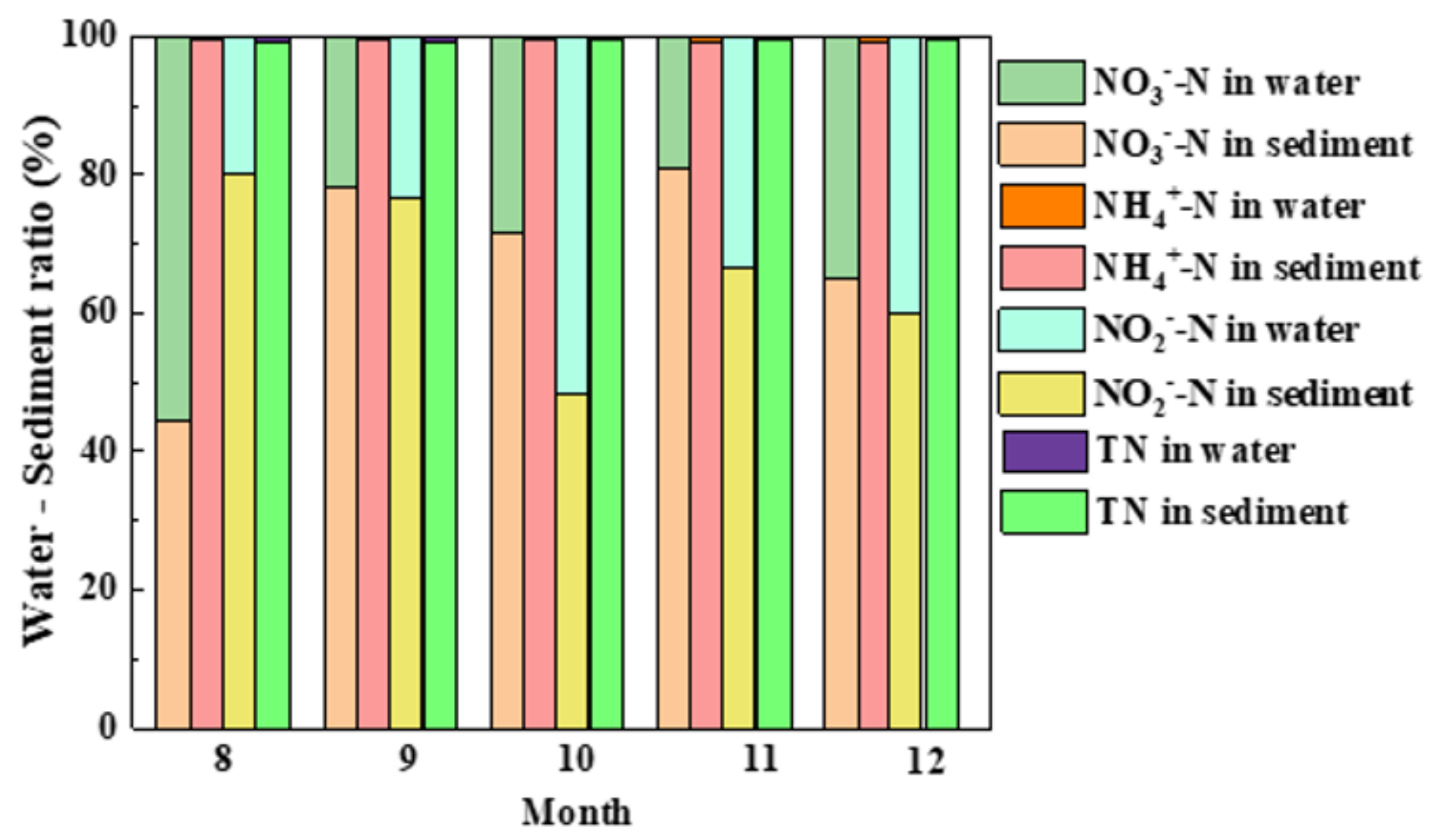

Figure 7

Temporal distribution of nitrogen pollutants in hybrid CW 


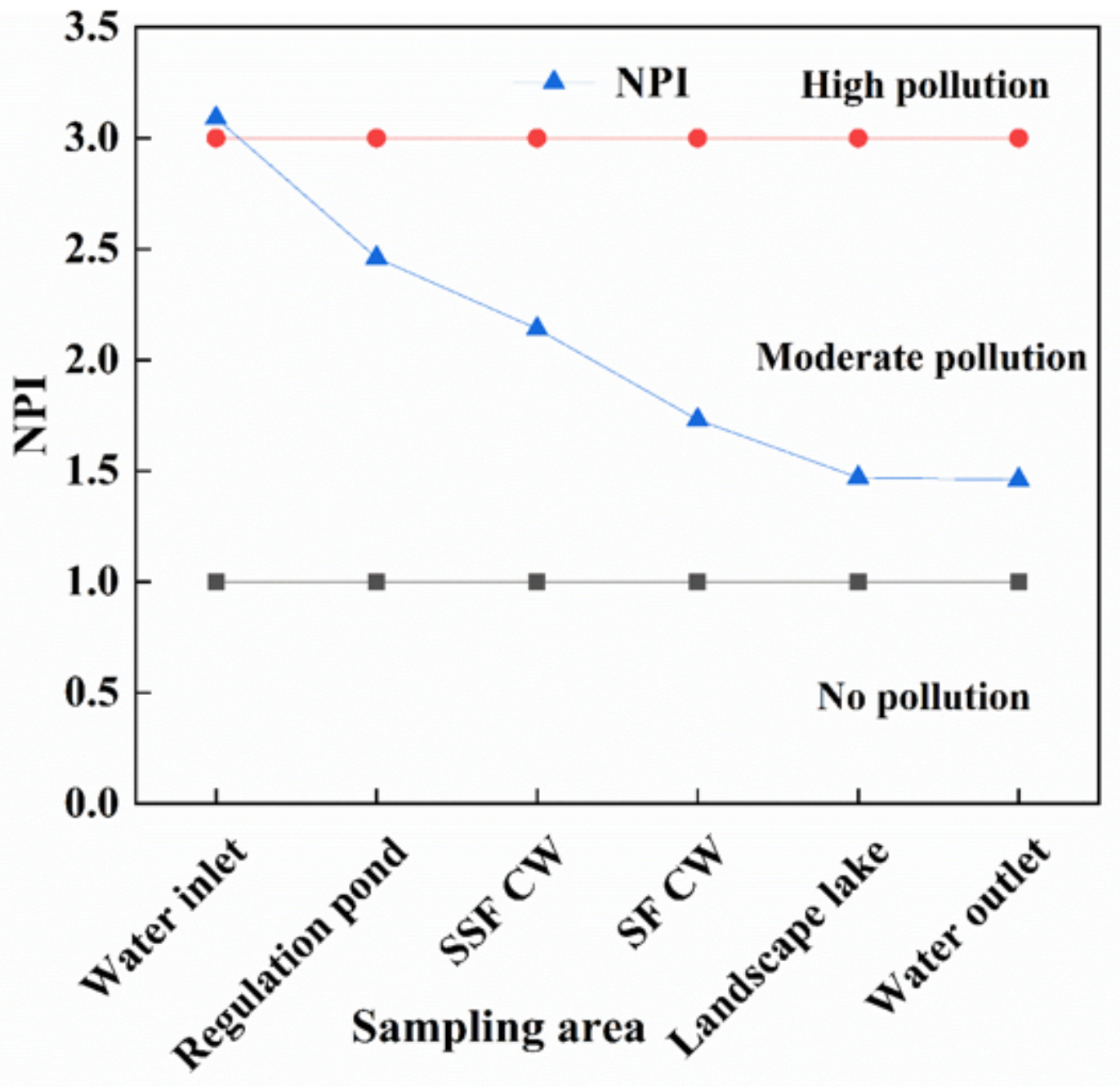

Figure 8

Nutrient pollution index 